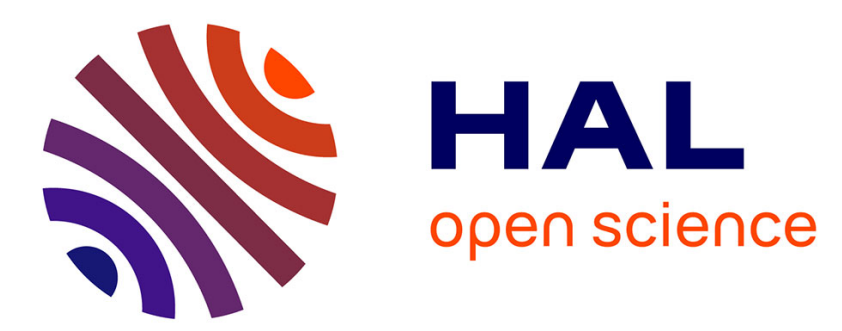

\title{
FT-IR STUDY OF THE OH SURFACE GROUPS ON CORDIERITE AEROGEL
}

\author{
M.-I. Baraton, T. Merle-Mejean, P. Quintard, V. Lorenzelli
}

\section{To cite this version:}

M.-I. Baraton, T. Merle-Mejean, P. Quintard, V. Lorenzelli. FT-IR STUDY OF THE OH SURFACE GROUPS ON CORDIERITE AEROGEL. Journal de Physique Colloques, 1989, 50 (C4), pp.C4-239C4-243. 10.1051/jphyscol:1989439 . jpa-00229523

\section{HAL Id: jpa-00229523 https://hal.science/jpa-00229523}

Submitted on 1 Jan 1989

HAL is a multi-disciplinary open access archive for the deposit and dissemination of scientific research documents, whether they are published or not. The documents may come from teaching and research institutions in France or abroad, or from public or private research centers.
L'archive ouverte pluridisciplinaire HAL, est destinée au dépôt et à la diffusion de documents scientifiques de niveau recherche, publiés ou non, émanant des établissements d'enseignement et de recherche français ou étrangers, des laboratoires publics ou privés. 
FT-IR STUDY OF THE OH SURFACE GROUPS ON CORDIERITE AEROGEL

\author{
M.-I. BARATON, T. MERLE-MEJEAN, P. QUINTARD and V. LORENZELLI* \\ Laboratoire de spectrometrie Vibrationnelle, CNRS UA-320, 123 Avenue \\ Albert Thomas, F-87060 Limoges, France \\ *Istituto di Chimica, Facolta di Ingegneria, Ple Kennedy, I-16129 \\ Genova, Italie
}

\begin{abstract}
Résumé - Nous avons étudié une cordiérite à haute surface spécifique par spectroscopie infrarouge en transmission. Après activation des échantillons, nous avons mis en évidence la présence des groupes hydroxyles. L'action du méthanol et l'échange isotopique avec le deutérium ont prouvé que tous ces groupes sont liés aux atomes de silicium de surface.
\end{abstract}

\begin{abstract}
A high specific surface area cordierite has. been investigated by infrared transmission spectroscopy. After activation of the samples, we have evidenced the presence of hydroxyl groups. Treatments with methanol and isotopic exchange with deuterium have proved that all of them are bound to the surface silicium atoms.
\end{abstract}

\title{
1 - INTRODUCTION
}

Cordierite is a ceramic material promising in the electronic and catalytic fields. The study of these catalytic properties goes through the investigation of the surface. From this viewpoint, the Fourier transform infrared (FT-IR) spectroscopy is a very useful tool as long as the specific surface area of the compound is high enough. The sol-gel preparation process provides us with such a surface area which allows to characterize the $\mathrm{OH}$ groups on cordierite as a first step of a surface study.

\section{2 - EXPERIMENTAL}

The preparation of cordierite aerogel has been related elsewhere $/ 1,2 /$. According to this process, the aerogel is obtained with a high specific surface area $\left(400 \mathrm{~m}^{2} \cdot \mathrm{g}^{-1}\right)$, a low density (0.3) and hydrophylic character. The properties of the bulk have previously been studied $/ 3 /$.

The spectra are recorded using a FT-IR spectrometer (Nicolet 5DX) with a $4 \mathrm{~cm}^{-1}$ resolution. Cordierite is pressed in grid-supported pellets. The samples are introduced inside a vacuum heatable cell allowing in-situ experiments. We have activated them by heating up to $723 \mathrm{~K}$ and then cooling down to room temperature, both under evacuation. Prior to any introduction of adsorbates the pressure is about $10^{-6} \mathrm{mB}$.

Methanol (RP Normapur from Prolabo) is dried on molecular sieves before adding. $\mathrm{D}_{2}$ (from Alphagaz-Air liquide) is used as provided. 


\section{3 - RESULTS AND DISCUSSION}

The spectrum of an activated sample presents a sharp absorption band at $3747 \mathrm{~cm}^{-1}$ (figure la). As in silica $/ 4,5 /$, it is assigned to the $v(O H)$ stretching vibration of the surface silanol groups, free from any hydrogen bond. On the cordierite surface, we can expect to find $\mathrm{OH}$ groups bound to $\mathrm{Al}$ and $\mathrm{Mg}$ atoms whose vibration frequencies are at $3700,3745,3760$ and $3785 \mathrm{~cm}^{-1}$ (Al-OH.on $\mathrm{Y}-$ alumina) and at 3752 and $3610 \mathrm{~cm}^{-1}$ (Mg-OH on magnesia) /6/. However, we have been unable to evidence these absorptions. This lack of the expected bands has already been noticed on silicaalumina /4/ and $\mathrm{Mg} \mathrm{Al}_{2} \mathrm{O}_{4} / 7 /$.

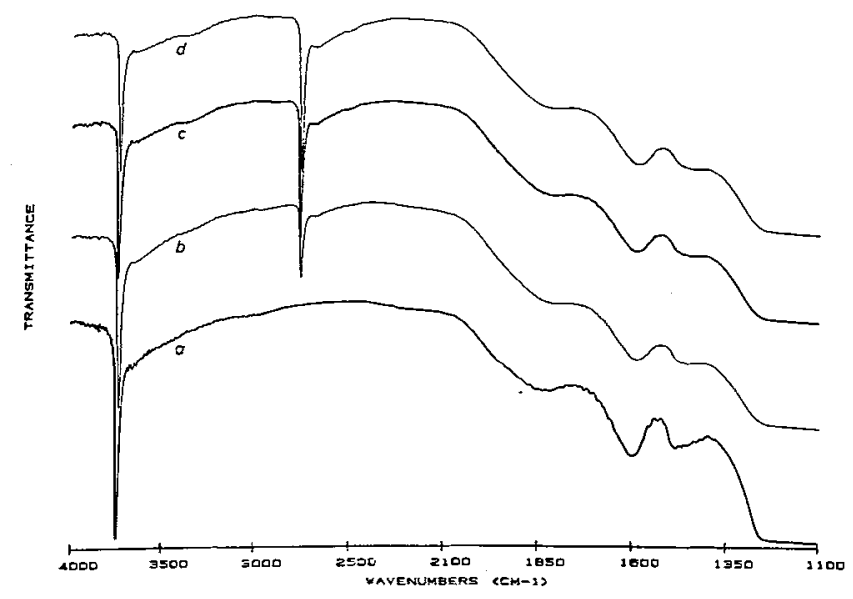

Fig. 1 - Evolution of the cordierite spectrum after addition of $D_{2}$ : Spectrum of the activated cordierite (a). Addition of $7 \mathrm{mB} \mathrm{D}_{2}$ at $673 \mathrm{~K}$ for $10 \mathrm{mn}$ (b), $30 \mathrm{mn}$ (c) and $60 \mathrm{mn}$ (d).

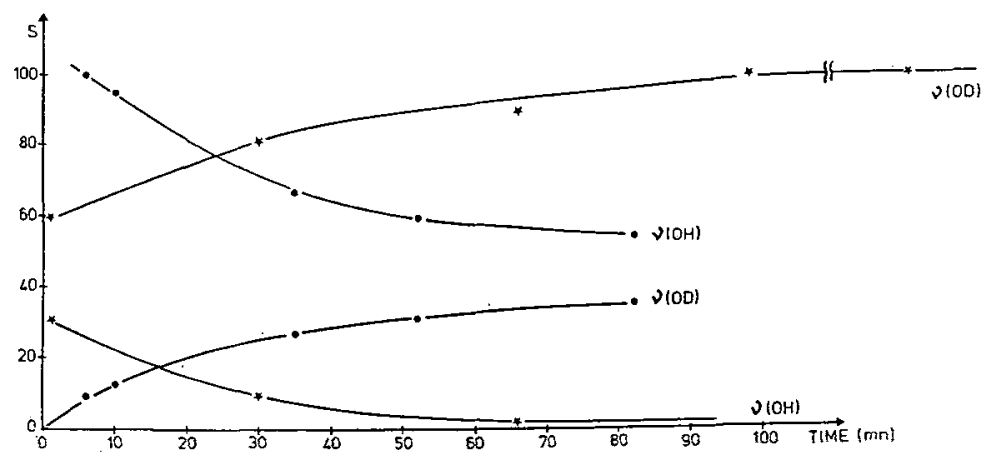

Fig. 2 - Isotopic exchange - Integrated surface (S) versus time : 1 st dose $P\left(D_{2}\right)=6 \mathrm{mB}-$ $*$ 2nd dose $P\left(D_{2}\right)=355 \mathrm{mB}$. 
After adding $7 \mathrm{mB}$ of $\mathrm{D}_{2}$ at $673 \mathrm{~K}$ to the activated sample, we observe a sharp band occuring at $2760 \mathrm{~cm}^{-1}$ (figure 1) attributed to the $v(O D)$ stretching mode, while simultaneously the intensity of the $v(\mathrm{OH})$ band decreases. The isotopic exchange does not proceed to completion under a low pressure, even by adding subsequent doses. The intensity ratios of the $v(\mathrm{OD})$ and $v(\mathrm{OH})$ bands have been calculated as functions of the contact times, the temperatures of the sample and the doses. Some results are given in figure 2 : whatever the dose and the pressure are the curves $v(\mathrm{OH})$ and $\checkmark(O D)$ versus the time follow the same evolution, with an asymptotic behavior corresponding to the exchange equilibrium.

A pressure higher than $200 \mathrm{mB}$ is needed to reach the complete exchange even though it is not spontaneous but a rather slow process. It is totally reversible by introducing $\mathrm{H}_{2}$.

So we can conclude that all the $\mathrm{OH}$ groups are located on the surface.

Adsorbed methanol on the cordierite surface gives rise to many bands over two main regions : 3700 $-2800 \mathrm{~cm}^{-1}$ and $1500-1300 \mathrm{~cm}^{-1}$. We were particularly interested in the first range corresponding to the absorption of the $v(\mathrm{OH})$ stretching vibrations (figure 3). Adding $0.07 \mathrm{mB}$ of methanol at room temperature leads to the disappearance of the $v(\mathrm{OH})$ at $3747 \mathrm{~cm}^{-1}$ and the appearance of a broad band centered at $3375 \mathrm{~cm}^{-1}$ and of two sharp bands $\left(2966\right.$ and $2853 \mathrm{~cm}^{-1}$ ) with shoulders (2997 and $2921 \mathrm{~cm}^{-1}$ ).

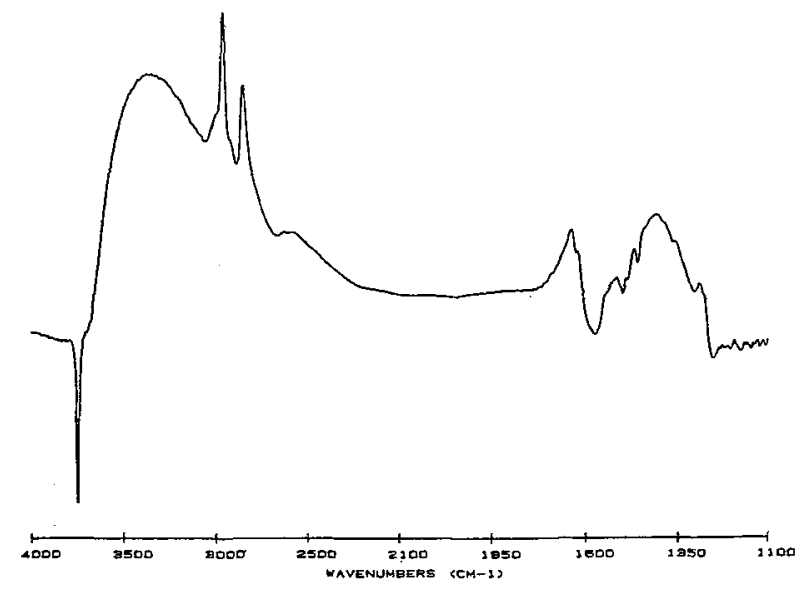

Fig. 3 - Difference spectrum featuring the modification of the cordierite spectrum after adding 0.07 $m B$ of methanol at room temperature.

The first two features result from the formation of a hydrogen bond between the surface silanols and the methanol $\mathrm{OH}$ group. The $v(\mathrm{CH})$ stretching frequencies of $\mathrm{H}$-bonded methanol should be slightly perturbed compared with the free molecule.

Under evacuation at room temperature, a very few silanol groups are restored, but at $373 \mathrm{~K}$ we observe the decreasing of the $3350 \mathrm{~cm}^{-1}$ band and of both 2966 and $2841 \mathrm{~cm}^{-1}$ bands, included their shoulders (figure 4). We therefore assign them to the $v(\mathrm{CH})$ stretching vibrations of the H-bonded methanol. 

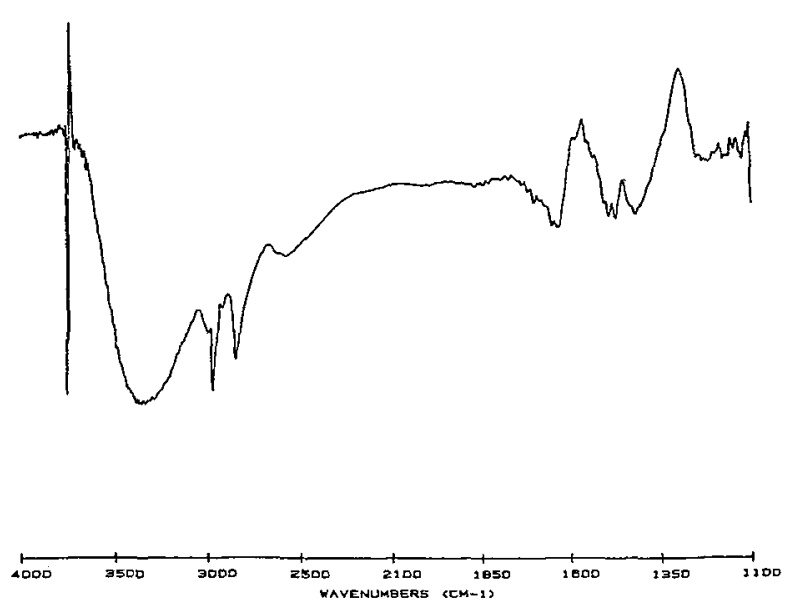

Fig. 4 - Difference spectrum : the evolution of the spectrum of methanol adsorbed on cordierite by evacuation at $373 \mathrm{~K}$. The modification of the band at $3747 \mathrm{~cm}^{-2}(\mathrm{v}(\mathrm{OH})$ ) is partly due to a temperature effect $/ 10,11 /$.

However, after pumping off for one hour at $673 \mathrm{~K}$ the spectrum of cordierite still presents two weak bands at 2964 and $2856 \mathrm{~cm}^{-1}$ (figure 5). At this temperature the $\mathrm{H}$-bond no longer exists. Comparing with silica $/ 8 /$, we attribute them to methoxyl group on silicium ( $\mathrm{Si}-\mathrm{OCH}_{3}$ ). Not all the sample is methylated at room temperature and under that pressure. Neither was the silica surface even at higher temperature and under saturated methanol vapour, because of the steric hindrance preventing a complete reaction $/ 9 /$.

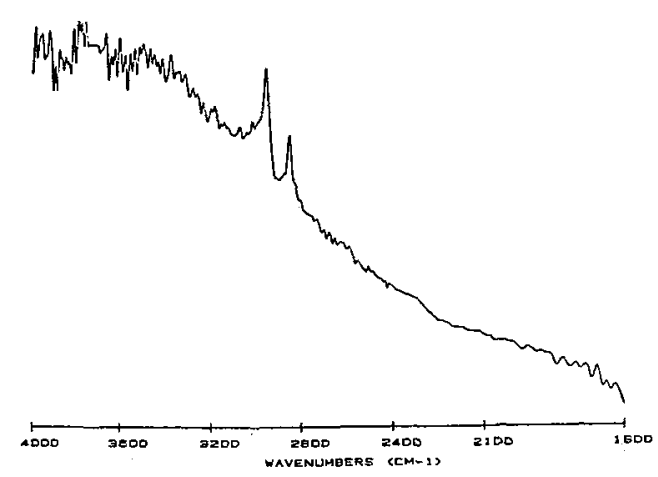

Fig. 5 - Difference spectrum : adsorbed methanol on the cordierite surface after evacuation at $673 K$. 


\section{4 - CONCLUSION}

By FT-IR spectroscopy we have pointed out that all the $\mathrm{OH}$ groups of cordierite are located on the surface. Their stretching vibration frequency and their behavior regarding deuteration and methyllation look very much the same as in silica.

So we can conclude that all the evidenced $\mathrm{OH}$ groups belong to the silanol species. No absorption frequency corresponding to $\mathrm{Al}-\mathrm{OH}$ or $\mathrm{Mg}-\mathrm{OH}$ surface groups has been observed so far. Experiments are still running for characterizing the other catalytic sites on the cordierite surface and their acidic or basic activities.

The authors are indebted to Dr H: VESTEGHEM (E.N.S.C.I., Limoges, France) for providing them with cordierite aerogels.

\section{References}

11/ VESTEGHEM H, DI GIAMPOLO A.R. and DAUGER A., J. Mater. Sci. Letters, 6 (1987) 1187.

12/ DI GIAMPOLO A.R., Thesis, Limoges (1987).

13/ MERLE-MEJEAN T., VESTEGHEM H., QUINTARD P. and LORENZELli V., J. Molecular Struct., 175 (1988) 401.

141 HAIR M.L., Infrared Spectroscopy in Surface Chemistry, M. Decker Ed., New York (1967).

15/ BOEHM H.P. and KNOZINGER H., Catalysis, Vol 4, J. R. Anderson and M. Boudart Ed., Springer-Verlag, Berlin, New-York (1983).

16/ KNOZINGER H., Advances in Catalysis, 25 (1976) 184.

171 MORTERRA C., GHIOTTI G., BOCUZZIF. and COLUCCIA S., J. Catalysis, 51 (1978) 299.

181 MORROW B.A., J. Chem. Soc. Faraday Trans. I., 70 (1974) 1527.

19/ LITTLE L.H., Infrared Spectra of Adsorbed Species, Academic Press, London (1966).

/10/ MORROW B.A. and CODY I.A., J. Phys. Chem., 77 (1973) 1465.

/11/ PERI J.B., J. Phys. Chem., 70 (1966) 2937. 